\title{
PERAN SUPERVISOR DALAM MENINGKATKAN KEDISIPLINAN ADMINISTRASI GURU DI SEKOLAH DASAR
}

\author{
Rina Wahyuni \\ FKIP, Universitas Palangka Raya \\ E-mail: rina.wahyuni@mp.upr.ac.id
}

\begin{abstract}
Abstrak: Berkenaan dengan perannya sebagai supervisor, kepala sekolah dituntut untuk dapat meningkatkan kedisiplinan guru yang ada di sekolah, antara lain dalam hal administrasi. Namun, pada kenyataannya masih terdapat beberapa guru yang kurang disiplin dalam menyelesaikan administrasinya di sekolah. Penelitian ini menggunakan pendekatan kualitatif, dengan rancangan studi kasus. Pengumpulan data dilakukan dengan teknik observasi, wawancara mendalam, dan dokumentasi. Hasil penelitian yang diperoleh menunjukkan peran supervisor dalam meningkatkan kedisiplinan administrasi guru sudah baik dan sangat solutif dalam meningkatkan kedisiplinan administrasi guru di sekolah. Meskipun masih ditemukan beberapa oknum guru yang kurang disiplin, namun hal tersebut dapat diatasi dengan adanya program supervisi (pembinaan) yang diberikan oleh kepala sekolah selaku supervisor.
\end{abstract}

Kata Kunci: Supervisor, Kedisiplinan, Administrasi Guru.

Abstract: With regard to its role as supervisor, the principal is required to be able to improve the discipline of teachers in the school, including administration. However, in reality there are still some teachers who lack discipline in completing their administration at school. This study used a qualitative approach with case study design. Data collection is done by observation, in-depth interviews, and documentation. The results of the research obtained indicate the role of supervisors in improving the discipline of teacher administration is good and very solutive in improving the discipline of teacher administration in schools. Although there are still some teachers who are lacking in discipline, this can be overcome by the supervision program provided by the principal as the supervisor.

Keywords: Supervisor, Discipline, Teacher Administration.

\section{PENDAHULUAN}

Di zaman era digital seperti sekarang ini, begitu banyak ditemukan perubahan-perubahan khususnya dalam pembentukan kepribadian diri seseorang. Banyak yang melihat bahwa perkembangan teknologi saat ini memiliki berbagai dampak, baik itu dampak positif maupun negatif. Dampak positif yang dapat dirasakan dengan adanya kemajuan teknologi saat ini ialah adanya kemudahan dalam mengakses segala bentuk data maupun informasi mengenai apapun yang ada di dunia. Sedangkan dampak negatif yang seringkali dialami ialah pemanfaatan kemajuan teknologi yang disalahgunakan oleh berbagai oknum-oknum terutama yang dapat merusak pikiran, perkataan maupun sikap dari diri seseorang.
Sekolah sebagai lembaga pendidikan formal bertujuan membentuk manusia yang berkepribadian, mengembangkan intelektual peserta didik dalam rangka mencerdaskan kehidupan bangsa. Kepala sekolah sebagai pemimpin perannya sangat penting untuk membantu guru dan stafnya. Untuk meningkatkan kualitas pendidikan seorang kepala sekolah harus mampu meningkatkan disiplin para guru atau bawahannya. Banyak faktor yang dapat mempengaruhi disiplin seseorang, sebagai pemimpin begitu juga sebagai kepala sekolah, kepala sekolah harus mampu memberikan contoh-contoh yang dapat menyebabkan guru tergerak untuk melaksanakan disiplin secara efektif sehingga Disiplin mereka akan lebih baik. Sebagai pemimpin yang mempunyai pengaruh, ia berusaha agar 
nasihat, saran dan jika perlu perintahnya di ikuti oleh guru-gurutanpa adanya paksaan. Dengan demikian ia dapat mengadakan perubahan-perubahan dalam cara berfikir, sikap, tingkah laku orang-orang yang dipimpinnya. Dengan kelebihan yang dimilikinya yaitu kelebihan pengetahuan dan pengalaman, ia membantu guru-guru berkembang menjadi guru yang berdisiplin tinggi terutama dalam melaksanakan pembelajarannya di kelas. Seorang kepala sekolah adalah motor penggerak keberhasilan tujuan sekolah, karena dia adalah pemimpin di lingkungannya. Kepala sekolah harus mampu menggerakkan dengan baik dengan usaha yang optimal sehingga keseluruhan tujuan organisasi yang dipimpinnya dapat tercapai dengan baik. Semua usaha kepala sekolah merupakan kemampuan seorang kepala sekolah dalam mempengaruhi individu atau kelompok yang dipimpinya melalui suatu proses untuk mencapai tujuan organisasi.

Peningkatan disiplin guru utamanya dimulai dari sekolah. Posisi kepala sekolah sebagai leader dan manajer sekolah sangat penting perannya melalui upaya yang direncanakan secara efektif dan efisien, baik buruknya kualitas disiplin guru pada suatu sekolah erat kaitannya dengan usaha atau upaya kepemimpinan kepala sekolah dalam mengendalikan, memacu dan meningkatkan segala potensi, dan peraturan yang ada sebagai salah satu fungsi manajemen. Peningkatan disiplin dan kompetensi guru tidak begitu saja lepas dari peranan dan usaha kepala sekolah dalam menjalankan tugas pokok dan fungsinya sebagai kepala sekolah sedemikian rupa sehingga kondisi dan hasil pembelajaran dapat tercapai sesuai dengan tujuan yang hendak dicapai. Salah satu usaha atau upaya menciptakan kondisi diatas adalah dengan terus mengusahakan dan mengupayakan peningkatan disiplin guru.

Namun dewasa ini, begitu banyak ditemukan permasalahan terkait kedisiplinan guru di sekolah, salah satunya berkenaan dengan kurangnya kedisiplinan guru dalam administrasi pembelajaran di sekolah. Hai itu terlihat dari pandangan guru maupun kepala sekolah bahwa administrasi pembelajaran hanya merupakan formalitas dalam pembelajaran sehingga tidak perlu dibuat secara rinci dan sistematis. Hal itu mengakibatkan guru-guru menjadi tidak disiplin dan cenderung malas dalam mempersiapkan administrasi pembelajaran sebelum melaksanakan proses pembelajaran di sekolah. Permasalahan administrasi yang sering terjadi ialah: (1) guru masih sering lupa membuat RPP di setiap awal semester; (2) guru tidak pernah menyiapkan buku khusus untuk merekap nilai-nilai siswa sehingga nilai harian siswa dan nilai-nilai lainnya dihitung "luar kepala"; (3) guru sangat jarang menuliskan kemajuan pembelajaran setiap harinya; serta (4) guru tidak pernah membuat seberapa besar daya serap siswa terhadap pelajaran yang telah diberikan di kelas.

\section{METODE}

Penelitian ini menggunakan pendekatan kualitatif dengan rancangan studi kasus. Studi kasus yang pada hakekatnya meneliti kasus, manakala kasus tersebut diperlukan dan penting untuk "menguji" suatu teori yang telah tersusun dengan baik. Studi kasus juga dimaknai kasus organisasi, yaitu studi kasus untuk mendapatkan informasi tentang keterangan-keterangan organisasi dimana peneliti ingin mengetahui bagaimana kehidupan orang-orang dalam organisasi tersebut. Penelitian dilakukan di SDN 1 Bukit Tunggal Kota Palangka Raya. Penentuan informan dilakukan dengan teknik pengambilan sampel secara purposive sampling dan snowball sampling dengan maksud agar diperoleh data dan informasi dari orang-orang yang benar-benar mengetahui secara mendalam terkait fokus penelitian sehingga data yang diterima dapat lebih akurat. Dari informan 
pertama, maka akan berkembang ke informan kedua dan seterusnya sehingga diibaratkan seperti bola salju. Hal itu sejalan dengan yang dikatakan oleh Ulfatin (2014), begitu informan kunci pertama diwawancarai secukupnya, ia diminta untuk menunjukkan satu atau lebih sumber lain yang dianggapnya memiliki informasi yang dianggap relevan dan memadai, sehingga dapat dijadikan sebagai informan berikutnya. Teknik pengumpulan data yang digunakan adalah (a) observasi, (b) wawancara mendalam, dan (c) studi dokumentasi. Informasi yang terkumpul dari ketiga teknik tersebut dianalisis secara berulang dengan menggunakan alur pola interaktif Analisis data penelitian Miles dan Huberman yang meliputi reduksi data, penyajian data, dan penarikan kesimpulan. Pengecekan kredibilitas data dilakukan dengan teknik triangulasi (sumber dan teknik/metode), dan member checks; pengecekan dependabilitas data penelitian dilakukan oleh peneliti mulai dari melakukan penelitian, menyusun transkrip wawancara sampai dengan penulisan laporan hasil penelitian dan pelaksanaan penelitian sesuai dengan jadwal yang telah ditentukan; dan pengecekan konfirmabilitas digunakan untuk melihat bahwa hasil penelitian yang dilakukan menunjukkan adanya proses penelitian di lapangan.

\section{HASIL DAN PEMBAHASAN}

Hasil penelitian yang diperoleh terkait peran supervisor dalam meningkatkan kedisiplinan administrasi guru di sekolah, yaitu: pertama, upaya supervisor dalam meningkatkan kedisiplinan administrasi guru di sekolah menuunjukkan: (a) kedisiplinan administrasi guru menjadi salah satu program pembinaan (supervisi) terhadap guru yang terencana dengan baik dan dilakukan secara berjadwal pada tiap semesternya; (b) dalam rangka meningkatkan kedisiplinan administrasi guru, supervisor memberikan catatan- catatan yang berupa arahan dan bimbingan yang disesuaikan dengan kebutuhan guru; dan (c) supervisor memberikan peringatan/ teguran kepada guru yang masih belum menyelesaikan administrasinya, membuat pernyataan tertulis terhadap guru yang masih kurang disiplin, serta selalu melakukan pemantauan agar ketidakdisiplinan guru tidak terulang. Kedua, persepsi guru terhadap supervisor dalam meningkatkan kedisiplinan administrasi guru di sekolah menunjukkan bahwa: (a) guru sangat merespon positif bahkan merasa senang dengan adanya program pembinaan (supervisi) yang dilakukan dalam hal meningkatkan kedisiplinan administrasi guru di sekolah; dan (b) guru secara langsung merasakan berbagai manfaat dalam proses peningkatan disiplin administrasi tersebut, antara lain: guru merasa lebih bertanggungjawab dalam melaksanakan tugasnya sebagai pendidik yang professional, guru menjadi lebih disiplin dalam hal persiapan proses pembelajaran, guru menjadi lebih terbuka dan mampu menjalin hubungan yang baik dengan rekan sejawat maupun dengan supervisor sehingga dengan demikian menjadikan para guru dapat saling bertukar informasi terutama dalam hal perbaikan, pengembangan serta peningkatan proses pembelajaran ke arah yang lebih baik. Dan ketiga, faktor pendukung dan penghambat bagi supervisor dalam meningkatkan kedisiplinan administrasi guru di sekolah, menunjukkan bahwa: (a) faktor pendukung bagi supervisor dalam rangka meningkatkan kedisiplinan administrasi guru di sekolah didasari atas dasar keinginan, kesadaran dan motivasi yang tinggi dari guru yang bersangkutan untuk mau berubah dan memperbaiki diri ke arah yang lebih baik. Sedangkan (b) faktor penghambat dalam mencapai kedisiplinan administrasi guru yakni ketidakdisiplinan oknum guru yang memungkinkan dapat mempengaruhi guru-guru lain yang ada di sekolah; sehingga supervisor harus selalu 
melakukan pembinaan secara kontinyu dan memotivasi guru dalam rangka mencegah terjadinya hal dimaksud.

Hasil penelitian pada poin pertama yang berkenaan dengan upaya supervisor dalam meningkatkan kedisiplinan administrasi guru di sekolah sejalan dengan pendapat yang dikemukakan Muslim (dalam Berliani dan Wahyuni, 2017) bahwa penyusunan program supervisi harusnya disusun untuk masa waktu selama satu tahun ajaran. Oleh karena itu, dalam pengimplementasiannya diperlukan suatu rencana kegiatan yang lebih spesifik yang diprogramkan secara caturwulan atau semester, program bulanan dan program mingguan. Sehingga akan memberikan kejelasan tentang apa yang harusnya dilakukan supervisor dalam upaya mengimplementasikan program supervisi untuk masa waktu tertentu. Perencanaan program pembinaan dianggap sebagai suatu strategi untuk mencapai tujuan yang dibuat sebelum suatu tindakan, program dan kegiatan dilaksanakan. Dalam perencanaan dirumuskan, dipilih dan ditetapkan seluruh aktivitas-aktivitas sumber daya yang akan dilaksanakan dan digunakan dimasa yang akan datang untuk mencapai tujuan. Oleh karena itu, sebelum melaksanakan program pembinaan terhadap kedisiplinan administrasi guru, supervisor dan guru bersama-sama menyusun rencana/ program yang berkenaan dengan program pembinaan guru mulai dari tujuan yang harus dicapai, strategi yang digunakan dalam mencapainya, dan siapa saja yang terlibat di dalamnya. Hal itu sejalan dengan yang dikatakan oleh Sagala (2013), proses penyusunan rencana pendidikan merupakan hasil dari kesepakatan dan pengertian diantara penentu kebijakan degan anggota yang terkait tentang apa yang harus dicapai, bagaimana strategi mencapainya, dan siapa saja yang bertanggungjawab terhadap tugas-tugas tersebut. Lebih lanjut, Sukatin (2016) mengatakan supervisi (pembinaan) mempunyai peran mengoptimalkan tanggung jawab dari semua program. Supervisi (pembinaan) bersangkut paut dengan semua upaya penelitian yang tertuju pada semua aspek yang merupakan faktor penentu keberhasilan. Dengan mengetahui kondisi aspek-aspek tersebut secara rinci dan akurat, dapat diketahui dengan tepat pula apa yang diperlukan untuk meningkatkan kualitas organisasi yang bersangkutan.

Pemberian catatan sebagai wujud hasil dari pengecekan admnistrasi guru oleh supervisor dimaksudkan untuk memberikan arahan dan bimbingan kepada guru-guru dalam rangka melakukan perbaikan agar memperoleh hasil yang lebih optimal. Serupa dengan yang diungkapkan oleh Finch \& McGough (dalam Usman, 2013) bahwa tugas umum seorang pemimpin adalah memberikan pengarahan atau bimbingan. Pengarahan dan bimbingan diberikan guna meminimalisir terjadinya penyimpangan ataupun kesalahan yang dapat terjadi saat proses pelaksanaan. Hal ini sejalan dengan yang diungkapkan oleh Sagala (2013) berkenaan dengan tugas dan tanggungjawab guru yang sangat banyak baik yang terkait dengan kedinasan dan profesinya di sekolah. Seperti mengajar dan membimbing para muridnya, memberikan penilaian hasil belajar pada muridnya, mempersiapkan administrasi pembelajaran yang diperlukan, dan kegiatan lain yang berkaitan dengan pembelajaran. Sehingga sangat diperlukan adanya pembinaan yang diberikan oleh supervisor dalam rangka membimbing dan mengarahkan para guru.

Selain itu, dalam meningkatkan kedisiplinan administrasi guru di sekolah, supervisor telah melakukan berbagai upaya seperti memberikan peringatan/ teguran kepada guru yang masih belum menyelesaikan administrasinya, membuat pernyataan tertulis terhadap guru yang masih kurang disiplin, serta selalu melakukan pemantauan agar ketidakdisiplinan guru tidak terulang. Hal 
itu dilakukan guna meminimalisir ketidakdisiplinan yang terjadi khususnya dalam hal administrasi guru. Hasil penelitian ini sejalan dengan hasil penelitian yang dilakukan oleh Rahman (2014) terkait upaya peningkatan disiplin guru dalam mengajar yang sudah dilakukan oleh kepala sekolah di Sekolah Dasar Yayasan Mutiara Gambut yakni: 1) Memperkenalkan disiplin dan tata tertib (peraturan) kepada guru sehubungan dengan pelaksanaan kerja di sekolah, 2) Memberikan teguran/ peringatan bagi guru yang melanggar disiplin kerja, 3) Membuat pernyataan secara tertulis bagi guru yang melanggar disiplin dalam bekerja dengan maksud agar tidak terulang lagi pelanggaran yang sama, 4) Mengevaluasi pelaksanaan disiplin guru dalam mengajar apakah sudah berjalan dengan baik atau belum.

Hasil penelitian pada poin kedua yang berkenaan dengan persepsi guru terhadap supervisor dalam meningkatkan kedisiplinan administrasi guru di sekolah sesuai dengan pendapat yang diutarakan oleh Masaong (2013) mengemukakan tujuan utama supervisi (pembinaan) yaitu: (a) membimbing dan memfasilitasi guru mengembangkan kompetensi profesinya; (b) memberi motivasi guru agar menjalankan tugasnya secara efektif; (c) membantu guru mengelola kurikulum dan pembelajaran secara efektif; dan (d) membantu guru membina peserta didik agar potensinya berkembang secara maksimal. Dengan adanya program pembinaan (supervisi) yang dilakukan di sekolah, tentu saja hal tersebut berkenaan dengan peningkatan profesionalisme guru sebagai seorang tenaga pendidik. Guru yang bermutu niscaya mampu melaksanakan pendidikan, pengajaran dan pelatihan yang efektif dan efisien sesuai dengan tuntutan kurikulum yang berlaku. Dimana guru professional diyakini mampu memotivasi siswa untuk mengoptimalkan potensi-potensi yang dimiliki siswa dalam kerangkan pencapaian standar pendidikan yang ditetapkan. Sependapat dengan itu, Sagala (2013) menegaskan bahwa kompetensi professional mengacu pada perbuatan (performance) yang bersifat rasional dan memenuhi spesifikasi tertentu dalam melaksanakan tugas-tugas kependidikan. Untuk itu diperlukan program pembinaan (supervisi) dalam upaya memperbaiki kelemahan-kelemahan yang dimiliki guru. Dimana hal itu sejalan dengan Willes (dalam Muslim, 2013) bahwa supervisi merupakan bantuan bagi guru dalam perkembangan belajar mengajar agar lebih baik, atau dengan kata lain to be $a$ professional teacher.

Sedangkan hasil penelitian pada poin ketiga yang berkaitan dengan faktor pendukung dan penghambat bagi supervisor dalam meningkatkan kedisiplinan administrasi guru di sekolah sesuai dengan hasil penelitian Rahman (2014), dalam hasil penelitiannya ditemukan bahwa upaya peningkatan disiplin guru harus dimulai dari diri guru itu sendiri. Pada dasarnya orang yang disiplin dalam melaksanakan pekerjaannya adalah orang yang mempunyai kesadaran yang tinggi, ketepatan waktu, kepatuhan dalam melaksanakan tugas dan tanggung jawab yang tinggi terhadap pekerjaan yang diberikan yang diberikan kepadanya. Perilaku pribadi seorang guru sangat mempengaruhi disiplin guru, sebagai contoh dan teladan bagi siswa, hendaknya guru menerapkan sikap disiplin dari diri sendiri.

Ketidakdisiplinan guru dalam menyelesaikan administrasinya di sekolah dapat diatasi dengan memberikan pembinaan dan motivasi kepada guru secara kontinya. Seperti yang dikemukakan oleh Usman (2013) bahwa dalam memotivasi bawahannya, seorang leader berhadapan dengan dua hal yang mempengaruhi orang dalam pekerjaan, yaitu kemampuan dan kemauan. Kemauan dapat diatasi dengan pemberian motivasi, sedangkan kemampuan dapat diatasi dengan mengadakan diklat atau pelatihan. 
Dengan demikian, dapat dirumuskan bahwa kinerja manusia yang tampak dipengaruhi oleh fungsi motivasi dan kemampuannya. Lebih lanjut, Usman mengatakan bahwa motivasi merupakan keinginan yang terdapat pada individu yang merangsangnya untuk melakukan tindakan-tindakan atau sebagai alasan seseorang berperilaku. Sehingga ketidakdisiplinan seseorang dapat diminimalisir dengan pemberian motivasi yang dapat disesuaikan dengan karakter dari yang bersangkutan. Beberapa teknik motivasi yang dapat dilakukan adalah sebagai berikut: (a) berpikiran positif, (b) menciptakan perubahan yang kuat, (c) membangun harga diri, (d) memantapkan pelaksanaan, (e) membangkitkan orang lemah menjadi kuat, serta (f) membasmi sikap suka menunda-nuda. Oleh karena itu, Iskandar (2011) mengatakan bahwa kedisiplinan sangat perlu dalam menjalankan tugas dan kewajiban sebagai pengajar, pendidik dan pembimbing siswa. Disiplin yang tinggi akan mampu membangun kinerja yang profesional sebab pemahaman disiplin yang baik, guru mampu mencermati aturan-aturan dan langkah strategis dalam melaksanakan proses kegiatan belajar mengajar. Kemampuan guru dalam memahami aturan dan melaksanakan aturan yang tepat, baik dalam hubungan dengan personalia lain di sekolah maupun dalam proses belajar mengajar di kelas sangat membantu upaya membelajarkan siswa ke arah yang lebih baik. Kedisiplinan bagi para guru merupakan bagian yang tak terpisahkan dalam melaksanakan tugas dan kewajibannya sebagai seorang pendidik yang professional.

\section{SIMPULAN}

Berdasarkan hasil penelitian dan pembahasan yang telah diuraikan sebelumnya, dapat disimpulkan bahwa: Upaya supervisor dalam meningkatkan kedisiplinan administrasi guru, persepsi guru terhadap supervisor dalam meningkatkan kedisiplinan administrasi guru, serta faktor pendukung dan penghambat bagi supervisor dalam meningkatkan kedisiplinan administrasi guru sudah baik dan sangat solutif dalam meningkatkan kedisiplinan administrasi guru di sekolah. Meskipun masih ditemukan beberapa oknum guru yang kurang disiplin, namun hal tersebut dapat diatasi dengan adanya program supervisi (pembinaan) yang diberikan oleh kepala sekolah selaku supervisor. Diharapkan supervisor dapat lebih memberikan dorongan kepada guru-guru untuk semakin meningkatkan kedisiplinan administrasinya sebelum melaksanakan proses pembelajaran di sekolah; serta memberikan pembinaan, serta arahan kepada guru-guru untuk selalu menjalin komunikasi yang baik, baik itu dengan supervisor (kepala sekolah) maupun dengan rekan sesama guru sehingga menciptakan suasana dan iklim akademik yang mampu menunjang kelancaran komunikasi serta penerapan sistem pembelajaran yang lebih aktif, kreatif, dan berinovasi.

\section{UCAPAN TERIMA KASIH}

Ucapan terima kasih kami sampaikan kepada kepala SDN 1 Bukit Tunggal Kota Palangka Raya beserta guru-guru yang dengan ikhlas memberikan ijin, kesempatan serta meluangkan waktunya untuk menjadi informan dalam penelitian ini, serta Redaksi Equity in Education Journal (EEJ) yang telah memberikan kesempatan artikel kami dapat dimuat dalam jurnal ini.

\section{DAFTAR PUSTAKA}

Arikunto, S., \& Yuliana, L. (2012). $\begin{array}{ll}\text { Manajemen } & \text { Pendidikan. } \\ \text { Yogyakarta: } & \text { Aditya Media } \\ \text { Yogyakarta. } & \end{array}$

Asmani. (2012). Tips Efektif Supervisi Pendidikan Sekolah. Jogjakarta: DIVA Press.

Berliani, T., \& Wahyuni, R. (2017). Implementasi Supervisi oleh Kepala Sekolah dalam Meningkatkan 
Profesionalisme Guru. Jurnal Manajemen dan Supervisi Pendidikan, 1 (3): 218-226.

Bogdan, R. C., \& Biklen, S.K. (1992). Qualitative Research for Education, second edition. USA: Allyn and Bacon.

Ghony, D., \& Almanshur, F. (2012). Metodologi Penelitian Kualitatif. Jogjakarta: AR-RUZZ MEDIA.

Iskandar. (2011). Kedisiplinan Guru, (Online),

(https://urayiskandar.com/2011/02/ kedisiplinan-guru.html), diakses 23 Maret 2019.

Masaong, A. K. (2013). Supervisi Pembelajaran dan Pengembangan Kapasitas Guru. Bandung: Alfabeta.

Miles, H., \& Saldana. (2014). Qualitative Data Analysis A Methods Sourcebook. United States of America: SAGE Publications Inc.

Moleong, L. J. (2012). Metodologi Penelitian Kualitatif edisi revisi. Bandung: PT Remaja Rosdakarya.

Muslim. (2013). Supervisi Pendidikan Meningkatkan

Kualitas
Profesionalisme Guru. Bandung: Alfabeta.

Rahman. (2014). Peningkatan Disiplin Kerja Guru di Sekolah Dasar Yayasan Mutiara Gambut. Jurnal Bahana Manajemen Pendidikan, 2(1): 1-9.

Sagala, S. (2013). Kemampuan Profesional Guru dan Tenaga Kependidikan. Bandung: Alfabeta.

Sukatin. (2016). Manajemen Supervisi dalam Pendidikan. Jurnal Pendidikan Islam, 5(2): 221-240.

Usman, H. (2013). Manajemen; Teori, Praktik dan Riset Pendidikan. Jakarta: Bumi Aksara.

Wandhie. 2017. Pengertian Kedisiplinan, (Online), (https://wandhie.wordpress.com /pengertian-kedisiplinan/), diakses 23 Maret 2019.

Witaisma. (2013). Pengertian Kedisiplinan, (Online). (https://witaisma.wordpress.com/ 2013/05/19/a-pengertiankedisiplinan-kedisiplinan-adalahsuatu-kondisi-yang/), diakses 23 Maret 2019. 